\title{
PEMODELAN DAN SIMULASI KEBIJAKAN DENGAN PENDEKATAN SYSTEM DYNAMICS Kasus Permintaan Air PDAM di Salatiga
}

\author{
Yayuk Ariyani ${ }^{1}$, Samsubar Saleh ${ }^{2}$, dan Sotya Fevriera ${ }^{1}$ \\ ${ }^{1}$ Fakultas Ekonomika dan Bisnis, Universitas Kristen Satya Wacana, Salatiga \\ Jalan Diponegoro No. 52-60 , Salatiga, Jawa Tengah 50711 Telepon/Fax : 0298-311881, 0298-321212 \\ 2 Fakultas Ekonomika dan Bisnis, Universitas Gadjah Mada, Yogyakarta \\ Jalan Sosio Humaniora Bulaksumur, Yogyakarta 55281, Indonesia Telepon +62 0274548510 \\ E-mail: yayuk.ariani@mail.uksw.edu; sotya.fevriera@mail.uksw.edu
}

Diterima 21 Desember 2009/ Disetujui 5 Mei 2010

\begin{abstract}
About 58,83 percent of Salatiga population consumes water from PDAM (Perusahaan Daerah Air Minum) to fulfill their daily need. The demand for water, which is increasing in line with infrastructure development and economics growth in Salatiga while the availability of water is decreasing, lead to a lack of water in some regions in Salatiga. Therefore, a new policy is needed to solve this problem. Before that, a simulation of the policy is needed because it is not possible to do a direct research on the policy. Thus, this recent study attempts to model the phenomenon of demand for water in Salatiga with dynamics system approach since it can be used for a policy simulation. Based on the simulation result, it is suggested to solve the water scarcity problem by trying to reduce the rate of leaking in water distribution from 26 percent to 5 percent.
\end{abstract}

Keywords: demand for water, dynamics system, a lack of water, leakage of water distribution

\begin{abstract}
Abstrak: Sekitar 58,83 persen penduduk Salatiga mengkonsumsi air PDAM (Perusahaan Daerah Air Minum) untuk memenuhi kebutuhan sehari-hari. Permintaan air yang semakin meningkat sejalan dengan perkembangan infrastruktur dan pertumbuhan ekonomi di Salatiga. Ketersediaan air yang semakin menurun menyebabkan kekurangan air di beberapa daerah di Salatiga. Oleh karena itu perlu kebijakan baru untuk memecahkan masalah ini. Diperlukan suatu simulasi dari kebijakan baru tersebut, sebab tidak mungkin melakukan riset secara langsung terhadap kebijakan. Penelitian ini berusaha menyusun model fenomena permintaan air di Salatiga dengan pendekatan sistem dinamis karena dapat dipakai untuk simulasi kebijakan. Berdasarkan pada hasil simulasi, penyelesaian persoalan kelangkaan air disarankan dengan mengurangi tingkat kebocoran distribusi air dari 26 persen menjadi 5 persen saja.
\end{abstract}

Kata kunci: permintaan air, sistem dinamis, kelangkaan air, kebocoran distribusi air

\section{PENDAHULUAN}

Air merupakan sumber daya alam yang unik karena ketersediaan air bersih memegang peranan penting bagi kelangsungan hidup manusia, di antaranya untuk memproduksi pangan, pengembangan ekonomi dan kesejahteraan serta kesehatan manusia. Populasi yang meningkat dan peningkatan standar hidup manusia akan menambah permintaan air sehingga terjadi eksploitasi manusia terhadap air tanah, air permukaan, hutan, dan lahan pertanian untuk dijadikan tempat tinggal maupun pembangunan industri. Eksploitasi tersebut menyebabkan kekeringan pada musim kemarau, dan menimbulkan banjir pada musim hujan. Sementara peningkatan industri dan ren- 
dahnya kontrol pemerintah akan mengakibatkan limbah pabrik yang tidak didaur ulang mencemari air. Di samping itu, perubahan iklim akibat pemanasan global yang terjadi akhir-akhir ini diduga juga akan mempengaruhi curah hujan dan ketersediaan air.

Kota Salatiga yang terletak $40 \mathrm{~km}$ di sebelah selatan kota Semarang, memiliki luas daerah $56.781 \mathrm{~km}^{2}$ pada tahun 2006, dengan curah hujan $16 \mathrm{~mm} /$ hari pada tahun tersebut. Sekitar 58,83 persen masyarakat Salatiga memanfaatkan air PDAM (Perusahaan Daerah Air Minum) untuk memenuhi kebutuhan air sehari-hari. Masyarakat Salatiga lebih memilih menggunakan air yang disalurkan oleh PDAM karena tidak memungkinkan bagi masyarakat di daerah perkotaan untuk membuat sumur dalam (sumur artesis). Selain karena keterbatasan lahan, pembuatan sumur dalam oleh masyarakat (perorangan) harus mendapat ijin pemerintah daerah karena pembuatan sumur dalam sangat berpotensi menimbulkan kerusakan lingkungan. PDAM kota Salatiga memanfaatkan sumber air dari daerah Senjoyo yang terletak di Kabupaten Semarang dan beberapa sumber mata air dari daerah Salatiga.

Permintaan air di kota Salatiga semakin meningkat dari tahun ke tahun. Hal tersebut terbukti dengan meningkatnya volume air yang disalurkan dari PDAM pada tahun 2004 sebesar $7.220 .215 \mathrm{~m}^{3}$ menjadi $7.848 .630 \mathrm{~m}^{3}$ pada tahun 2005 (BPS, 2005). Peningkatan permintaan air tersebut terjadi seiring dengan perkembangan pembangunan dan pertumbuhan ekonomi di Salatiga.

Berdasarkan data di PDAM, pada tahun 2005 jumlah pelanggan PDAM Salatiga adalah 24.533 sambungan. Jumlah pelanggan tersebut meningkat pada tahun 2006 menjadi 24.721 sambungan. Dari total pelanggan pada tahun 2006 tersebut 83,79 persen adalah rumah tangga, 6,57 persen bisnis (industri dan niaga), 2,25 persen sosial dan 0,83 persen instansi pemerintah. Untuk memenuhi kebutuhan pelanggan yang terus meningkat, beberapa sumber air baru di daerah Salatiga telah diusahakan oleh PDAM Salatiga, diantaranya adalah sumber mata air Kali Gojek, Kali Sombo, Kali Taman dan Kali Gethek. Pada tahun 2008 PDAM membuat sumur dalam sebagai suber pasokan air, yaitu sumur Sukowati, yang terletak di jalan Sukowati Salatiga.

Beberapa tahun terakhir sebagian masyarakat Salatiga mulai mengeluh kekurangan air. Banyak penduduk yang mengeluhkan tidak lancarnya air dari PDAM, maupun kualitas air PDAM yang tidak baik, meskipun tarif PDAM sudah dinaikkan. Bahkan pada bulan Agustus tahun 2007 terdapat empat kelurahan yang kekurangan air bersih (wawasandigital.com). Peningkatan permintaan air di Salatiga merupakan tantangan pemerintah daerah, khususnya PDAM untuk dapat memenuhi kebutuhan air bagi rumah tangga maupun industri, dan perdagangan. Apalagi ketersediaan air semakin berkurang. Hal tersebut dibuktikan dengan penurunan debit air di mata air Senjoyo. Pada tahun 2000 debit air di Senjoyo mencapai 140 $\mathrm{cm}$, tetapi pada tahun 2006 debit air hanya sekitar $90 \mathrm{~cm}$ (digilib.ampl.or.id). Oleh karena itu pemerintah daerah Salatiga, khususnya PDAM perlu menentukan kebijakan untuk mengatasi kekurangan air yang mulai dirasakan oleh sebagian masyarakat Salatiga. Fenomena permintaan air sangat dipengaruhi oleh banyak faktor, di antaranya adalah tarif/harga air PDAM dan jumlah pelanggan yang dipengaruhi oleh pertumbuhan jumlah penduduk/ populasi.

Berdasarkan uraian di atas, terlihat bahwa kebutuhan air semakin meningkat, sementara ketersediaan air semakin berkurang. Hal itu melatarbelakangi penelitian untuk mengidenfitikasi faktor-faktor yang mempengaruhi peningkatan permintaan air PDAM di kota Salatiga yang selanjutnya digunakan untuk membangun model yang dapat menggambarkan fenomena ketersediaan dan permintaan air PDAM di Kota Salatiga dalam jangka panjang. Model tersebut dibangun dengan pendekatan system dynamics yang selain bisa digunakan untuk memodelkan fenomena yang terjadi, juga bisa digunakan untuk mensimulasikan alternatif kebijakan yang dapat diambil oleh pemerintah daerah untuk mengatasi permasalahan permintaan dan kekurangan air di Salatiga sehingga pada akhirnya akan dapat dirumuskan suatu kebijakan yang diharapkan akan efektif untuk mengatasi permasalahan yang terjadi. Metode system dynamics merupakan salah satu pende- 
katan pemodelan kebijakan terutama dalam hal peningkatan pemahaman tentang bagaimana (how) dan mengapa (why) gejala dinamis suatu sistem terjadi (Tasrif, 1998). Tujuan dari metodologi ini lebih ditekankan pada pengertian tentang bagaimana tingkah laku sistem muncul dari struktur kebijaksanaan dalam sistem itu, selanjutnya pengertian itu penting untuk perancangan kebijaksanaan yang efektif.

Teori Permintaan. Varian (1992), menyatakan bahwa fungsi permintaan konsumen adalah banyaknya barang optimal yang merupakan fungsi dari harga dan pendapatan dari konsumen. Dengan kata lain permintaan konsumen akan suatu barang sangat dipengaruhi oleh harga barang yang akan dibeli dan pendapatan yang dimiliki konsumen tersebut.

Sukirno (2002) menyatakan faktor yang dianggap penting dalam mempengaruhi permintaan adalah harga barang itu sendiri, harga barang lain yang erat kaitanya dengan barang tersebut, pendapatan rumah tangga dan pendapatan rata-rata masyarakat, corak distribusi pendapatan dalam masyarakat, cita rasa masyarakat, jumlah penduduk, ramalan mengenai keadaan di masa yang akan datang, dsb. Oleh karena sangat sukar menganalisis pengaruh faktor tersebut terhadap permintaan suatu barang maka para ahli ekonomi membuat analisis yang sederhana.

Dalam analisis ekonomi dianggap bahwa permintaan suatu barang terutama dipengaruhi oleh tingkat harga barang yang diminta tersebut. Dalam analsis tersebut diasumsikan bahwa faktor-faktor lain tidak mengalami perubahan atau ceteris paribus. Oleh karena itu hukum permintaan menyatakan bahwa apabila faktor lain dianggap tetap (ceteris paribus) maka semakin rendah harga suatu barang semakin banyak permintaan terhadap barang tersebut. Sebaliknya, semakin tinggi harga suatu barang semakin sedikit permintaan terhadap barang tersebut. Oleh karena analisis tersebut hanya memuat hubungan antara dua variabel maka dapat digambarkan kurva permintaan dalam suatu koordinat kartesius. Kurva permintaan adalah kurva yang menggambarkan hubungan antara harga suatu barang tertentu dengan jumlah barang yang diminta para pembeli.

Dalam penelitian ini permintaan air selain dipengaruhi oleh harga dan Pendapatan Domestik Regional Bruto (PDRB), juga dipengaruhi oleh populasi penduduk dan alih fungsi lahan. Populasi penduduk dipengaruhi antara lain oleh kelahiran, kematian, inmigrasi dan outmigrasi. Sedangkan alih fungsi lahan dipengaruhi oleh kebutuhan lahan non pertanian dan ketersediaan lahan pertanian yang berubah menjadi lahan non pertanian. Model yang lebih lengkap akan dijelaskan pada bagian metodologi penelitian.

Pertumbuhan Populasi, Pembangunan Ekonomi. Todaro (2006), dalam bukunya Economic Development menyatakan bahwa setiap tahun kurang lebih 80 juta jiwa lahir menambah populasi manusia di dunia. Pendapat yang ekstrim menyatakan bahwa populasi menimbulkan masalah dalam ekonomi. Pertumbuhan populasi yang cepat mempunyai konsekuensi yang serius untuk kehidupan manusia diantaranya adalah kemiskinan, standar hidup yang rendah, kekurangan gizi, kesehatan yang tidak terjamin, kerusakan lingkungan, dan persoalan sosial yang kompleks. Todaro menyatakan bahwa beberapa studi empiris mengkaji beberapa akibat negatif tingginya pertumbuhan populasi, di antaranya adalah pertumbuhan ekonomi, kemiskinan dan kesenjangan, pendidikan, kesehatan, makanan, lingkungan, dan migrasi internasional.

Todaro menyatakan bahwa tingkat pertumbuhan populasi diukur oleh persentase peningkatan atau penurunan ukuran populasi yaitu natural increase dan net international migration. Natural increase diukur dengan selisih kelahiran dan kematian, atau perbedaan antara fertilitas dan mortalitas. Net international migration biasanya diabaikan, karena pertumbuhan yang lebih diperhatikan.

Perekonomian Sektor Publik dan Analisis Kebijakan Publik. Sektor publik merupakan bagian dari perekonomian nasional yang dikendalikan oleh pemerintah (Gaspersz, 2004). Bagian dari perekonomian ini berkaitan dengan pemberian atau penyerahan jasa-jasa pemerintah kepada publik. Pada umumnya sektor publik menyangkut jasa-jasa seperti: keamanan, polisi, militer, jalan umum, transportasi umum, listrik, pendidikan, kesehatan, air bersih, dan lain-lain. Dalam mengendalikan perekonomian, 
pemerintah sering membuat kebijakan-kebijakan. Pembuatan kebijakan bukan hal yang mudah karena harus dapat mengatasi, dan mencakup berbagai kepentingan yang berbeda dari masyarakat. Kepentingan yang berbeda dalam masyarakat terkadang saling bertentangan.

Pembuatan kebijakan perlu dianalisis dan direncanakan dengan matang. Wimer dan Vining (Partowidagdo, 2004) menyatakan analisis kebijakan adalah ilmu yang menghasilkan informasi yang relevan dengan kebijakan publik. E.S Quade (Partowidagdo, 2004) menyatakan analisis kebijakan adalah suatu bentuk analisis yang menyajikan informasi sedemikian rupa sehingga dapat memberikan landasan bagi para pembuat kebijakan dalam mengambil kaputusan. Ducan Mac Rae (Partowidagdo, 2004) menyatakan analisis kebijakan diambil dari berbagai disiplin dan profesi yang tujuannya bersifat dekriptif (menjelaskan), evaluatif (mengevaluasi) dan preskriptif (memberikan petunjuk). William Dunn (Partowidagdo, 2004) menyatakan analisis kebijakan mempunyai tujuan yang bersifat penandaan (designative) dengan pendekatan empiris (berdasarkan fakta), bersifat penilaian dengan pendekatan evaluatif, dan bersifat anjuran dengan pendekatan normatif.

Air dan Barang Publik. Barang publik, menurut Fauzi (2006) didefinisikan sebagai barang di mana jika diproduksi, produsen tidak memiliki kemampuan mengendalikan siapa yang berhak mendapatkannya. Barang publik mempunyai sifat yang dominan, yaitu non-rivalry (tidak ada ketersaingan) dan non-excludable (tidak ada larangan), artinya sulit untuk melarang pihak lain untuk mengkonsumsi barang yang sama (Kusdiyanto, 2007:28-35).

Fauzi menyatakan bahwa seiring bertambahnya penduduk dan ekskalasi pembangunan ekonomi, fungsi ekonomi dan sosial air sering terganggu karena semakin kritisnya pasokan air, sementara permintaan air terus meningkat dari waktu ke waktu. Kekhawatiran inilah yang menyebabkan sumber daya air kemudian tidak lagi diperlakukan sebagai barang publik murni (pure public good) yang bisa dimanfaatkan sesuka hati, karena air tidak hanya diperlukan untuk kebutuhan hidup manusia, tetapi juga untuk menjaga ekosistem air yang berguna untuk kelangsungan hidup jangka panjang.
Air dan Klasifikasi Air. Salah satu sektor publik yang perlu diperhatikan adalah ketersediaan air. Air digolongkan sebagai sumber daya yang dapat diperbarukan dan tidak terbarukan (Fauzi, 2004). Air yang bersumber dari bawah tanah (groundwater) diperoleh melalui proses geologi selama ribuan tahun, sehingga jika jumlah yang dimanfaatkan melebihi kemampuan pemulihan kembali lewat hujan (recharge rate), ketersediaan air bawah tanah sulit diperbarukan kembali. Sedangkan air permukaan (surface water), seperti air yang diperoleh dari sungai atau danau dikategorikan sebagai sumber daya air yang terbarukan karena adanya proses hidrologi dari bumi. Menurut Dumairy (1992) berdasarkan tempat beradanya, air dibedakan menjadi tiga, yaitu air permukaan, air tanah dan air udara. Air permukaan adalah air yang terdapat di permukaan kulit bumi, baik yang berupa benda cair (sungai, danau) juga berupa benda padat (es, salju, gletser). Air tanah adalah air yang terdapat di bawah kulit bumi, atau di dalam tanah. Sedangkan air udara adalah air yang terdapat di dalam atmosfir bumi, berupa uap atau bintik-bintik hujan.

Dumairy (1992) mengklasifikasikan penggunaan air ke dalam tiga golongan, berdasarkan tujuan penggunaanya, yaitu air untuk keperluan irigasi, air untuk keperluan pembangkit energi, air untuk keperluan publik. Air untuk keperluan publik dibedakan atas air untuk konsumsi domestik, serta air untuk konsumsi sosial dan komersial. Air untuk keperluan publik adalah air yang digunakan untuk kepentingan manusia. Air untuk konsumsi domestik maksudnya ialah air yang dikonsumsikan oleh sektor rumah tangga, meliputi air untuk memasak, mencuci, minum, mandi, menyiram tanaman. Sedangkan air untuk konsumsi sosial dan komersial ialah air yang dikonsumsikan untuk keperluan publik selain sektor rumah tangga. Baik oleh lembaga publik, maupun lembaga swasta, seperti hotel, perkantoran, restauran, dan rumah sakit.

Air untuk keperluan irigasi adalah air yang digunakan untuk pertanian, dikonsumsi oleh tanaman, dan lahan tempat tanaman bertumbuh. Air untuk keperluan pembangkit energi adalah air yang digunakan untuk menggerakkan turbin pembangkit listrik tenaga air. Air 
untuk keperluan industri adalah air yang digunakan dalam proses pengolahan, sebagai salah satu bahan atau unsur dalam proses tersebut.

Penelitian ini dilakukan dengan tujuan untuk mengidentifikasi faktor-faktor apa yang memperngaruhi permintaan air di Salatiga. Berdasarkan faktor-faktor tersebut akan disusun model yang menggambarkan fenomena permintaan air di Salatiga. Melalui model tersebut akan dilakukan simulasi alternatif kebijakan oleh pemerintah daerah untuk mengatasi permasalahan permintaan dan kekurangan air di Salatiga.

\section{METODE PENELITIAN}

\section{Metode Analisis Data}

Seperti telah dijelaskan sebelumnya, analisis data pada penelitan ini menggunakan system dynamics. System dynamics telah berkembang sejak dekade 50-an, pertama kali dikembangkan oleh Forrester. Tujuan utama pemodelan system dynamics adalah memahami perilaku suatu sistem dengan menggunakan konsep matematis sederhana (Tangirala, 2003). Persoalan yang dapat dimodelkan menggunakan metodologi system dynamics adalah masalah yang mempunyai sifat dinamis (berubah terhadap waktu) di mana variabel-variabel yang digunakan dalam penelitian ini adalah variabel yang berubah setiap waktu, dan struktur fenomenanya mengandung paling sedikit satu struktur umpan balik/feedback structure.

Dalam metodologi system dynamics yang dimodelkan adalah struktur informasi sistem yang didalamnya terdapat aktor-aktor, sumbersumber informasi, dan jaringan aliran informasi yang menghubungkan keduanya. Pada dasarnya system dynamics memodelkan fenomena sesuai dengan data historis. Jika model tersebut mempunyai pola yang sesuai dengan data historis, maka barulah dapat dibuat simulasi kebijakan dengan menggunakan model tersebut karena model tersebut dapat dipakai untuk memprediksi ketersediaan, maupun kebutuhan air pada tahun-tahun yang akan datang. Singkatnya, model system dynamics tersebut dapat divalidasi dengan beberapa uji, yaitu: replikasi dan sensitivitas.
Langkah-langkah pemodelan dengan metode system dynamics adalah sebagai berikut (Tasrif, 2006):

\section{(1) Identifikasi perilaku persoalan (problem} behavior)

Pola Referensi. Dalam langkah ini diidentifikasi pola historis atau pola hipotesis yang menggambarkan perilaku persoalan. Pola historis yang dimaksud adalah pola data historis atau data pada tahun-tahun sebelumnya. Apabila data-data pada tahun sebelumnya tidak tersedia maka dapat menggunakan pola hipotesis, yaitu pola yang diduga oleh peneliti. Dalam penelitian ini, akan digunakan pola historis dengan melihat pola data tahun-tahun sebelumnya. Model yang dibuat nantinya harus sesuai dengan pola historis atau pola hipotesis tersebut sebelum model dapat digunakan untuk prediksi maupun simulasi.

Hypothesis Dynamics. Setelah pola referensi dapat didefinisikan, suatu hipotesis awal tentang interaksi-interaksi perilaku yang mendasari pola perilaku perlu diajukan. Hypothesis dynamics terkait dengan penelitian ini adalah diduga permasalahan air di Salatiga dapat diatasi dengan penambahan sumber air, mengatasi kebocoran distribusi air dan memperlambat pertumbuhan penduduk.

Batas Model. Penelitian ini akan dibatasi pada keterkaitan antara permintaan air, populasi dan alih fungsi lahan. Selain itu diasumsikan bahwa suplai air tetap.

(2) Menentukan suatu model komputer dengan software powersim

Struktur Umpan Balik Model. Setelah batas model didefinisikan, struktur umpan balik yang berinteraksi akan dibentuk. Struktur umpan balik ini merupakan blok pembentuk model yang diungkapkan melalui lingkar-lingkar tertutup (causal loop). Lingkar umpan balik tersebut menyatakan hubungan sebab akibat variabel-variabel yang melingkar, bukan menyatakan hubungan adanya korelasi-korelasi statistik. Model yang dibuat harus memuat minimal satu lingkar umpan balik. Penelitian ini menggunakan model dasar yang memuat satu lingkar umpan balik yang ditunjukkan pada Gambar 1. Tanda panah dalam Gambar 1 menyatakan variabel yang mempengaruhi dan variabel yang dipengaruhi. Sedangkan tanda \pm 
dalam gambar menunjukkan sifat hubungan antar variabel.

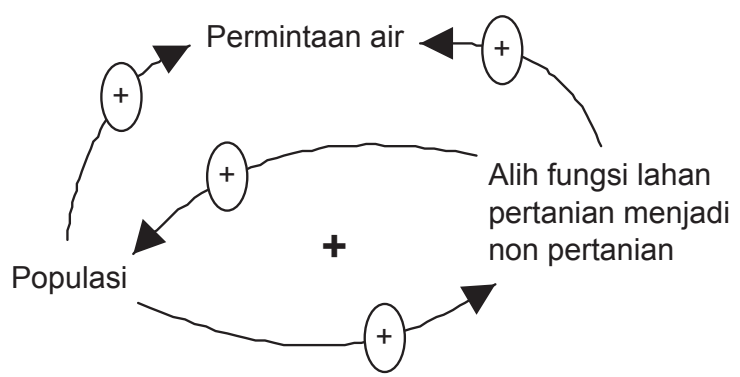

Gambar 1. Causal Loop Model Dasar

Pada Gambar 1 terdapat satu lingkar umpan balik (causal loop) yaitu antara populasi dan alih fungsi lahan. Semakin banyak populasi, alih fungsi lahan dari pertanian ke non pertanian (misalnya peralihan lahan pertanian menjadi lahan perumahan dan industri dan perdagangan) akan semakin meningkat. Sementara itu, peningkatan alih fungsi lahan pertanian ke non pertanian di suatu daerah akan semakin menarik orang untuk datang ke daerah tersebut sehingga populasi akan semakin meningkat. Peningkatan populasi tentu akan meningkatkan permintaan air. Di sisi lain, peningkatan alih fungsi lahan yang terjadi melalui proses pembangunan atau aktivitas bisnis juga akan meningkatkan permintaan air.

Model dasar tersebut kemudian dijabarkan lagi ke dalam empat submodel, yaitu submodel permintaan air, submodel populasi dan perumahan, submodel industri, serta submodel PDRB dan tenaga kerja yang selanjutnya akan dijabarkan satu per satu. Submodel tersebut saling terkait satu dengan yang lain, menjadi satu kesatuan yang tidak dapat dipisahkan.

Pada Gambar 2, volume air yang diproduksi PDAM akan meningkat apabila sumber air meningkat, tetapi akan berkurang apabila permintaan air dan kebocoran dalam distribusi air meningkat. Peningkatan volume air yang diproduksi PDAM akan menurunkan kekurangan air atau permintaan air yang tidak terpenuhi. Di sisi lain, peningkatan volume air yang diproduksi PDAM cenderung akan mendorong peningkatan total permintaan air. Permintaan air juga akan meningkat apabila permintaan air per pelanggan dan jumlah pelanggan meningkat. Tetapi sesuai hukum permintaan, permintaan air akan berkurang apabila tarif PDAM meningkat. Jumlah pelanggan PDAM akan meningkat seiring semakin bertumbuhnya populasi.

Submodel populasi dan perumahan yang dijelaskan dalam Gambar 3 menyatakan kelahiran dan migrasi masuk (perpindahan penduduk ke dalam suatu daerah) akan menambah populasi, sementara kematian dan migrasi keluar (perpindahan penduduk dari daerah ke luar dari suatu daerah) akan mengurangi populasi. Tingkat kelahiran dan kematian diduga akan menurun seiring meningkatnya kesejahteraan masyarakat yang dalam model ini menggunakan Pendapatan Regional Domestik Bruto (PDRB) sebagai pendekatan. Sementara, peningkatan populasi akan mendorong peningkatan permintaan terhadap rumah. Jumlah rumah yang semakin meningkat akan menyebabkan permintaan air semakin meningkat.

Pada Gambar 1 telah dijelaskan, permintaan air akan meningkat seiring peningkatan alih fungsi lahan melalui proses pembangunan atau

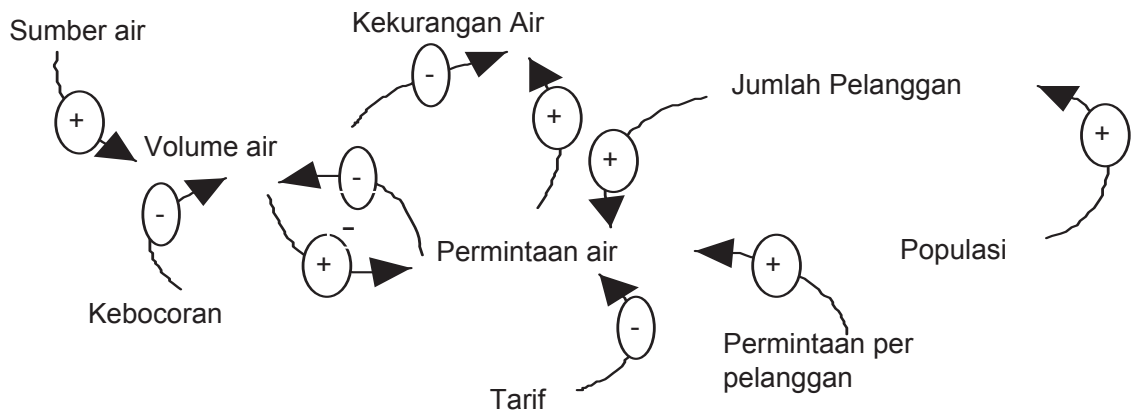

Gambar 2. Submodel Permintaan Air PDAM 


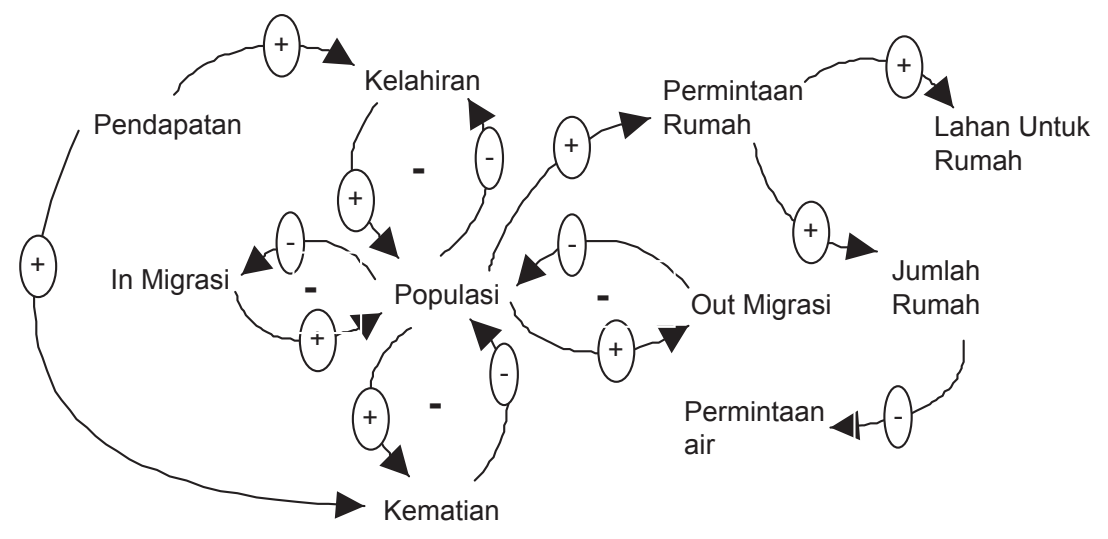

Gambar 3. Submodel Populasi dan Perumahan

aktivitas bisnis. Submodel bisnis dalam Gambar 4 menunjukkan aktivitas bisnis akan meningkat apabila terjadi pertumbuhan bisnis dan akan berkurang dengan adanya demolisi bisnis. Semakin tinggi aktivitas bisnis, maka pertumbuhan bisnis cenderung akan semakin meningkatkan pula. Di sisi lain, semakin meningkat aktivitas bisnis, persaingan dalam dunia bisnis akan semakin kuat sehingga demolisi bisnis akan semakin meningkat. Peningkatan aktivitas bisnis tentu akan meningkatkan kebutuhan lahan untuk bisnis. Sementara, semakin besar angkatan kerja, semakin banyak tenaga kerja yang tersedia untuk aktivitas bisnis sehingga pertumbuhan bisnis akan meningkat.

Pada model PDRB yang terdapat dalam Gambar 5, PDRB dianggap sebagai output yang dihitung dari fungsi produksi Cobb-Douglas. Semakin banyak kapital dan tenaga kerja yang digunakan dalam proses produksi, semakin banyak output yang dihasilkan. Kapital merupa- kan akumulasi dari investasi yang berkurang karena adanya depresiasi. Sementara kebutuhan tenaga kerja akan meningkat apabila tingkat produksi meningkat. Peningkatan kebutuhan tenaga kerja pada akhirnya akan mendorong peningkatan tenaga kerja. Peningkatan tenaga kerja akan menyebabkan peningkatan angkatan kerja. Angkatan kerja didefinisikan sebagai penduduk usia kerja, yaitu berumur lebih dari 15 tahun, yang sedang mencari pekerjaan atau mempunyai pekerjaan tapi untuk sementara tidak bekerja. Satuan Angkatan kerja adalah orang.

Model Komputer dengan Software Powersim. Model komputer dengan software powersim yang dimaksud adalah penyusunan model dengan menggunakan software komputer yang dalam hal ini adalah software powersim. Pembentukan model dengan software powersim tersebut dilakukan dengan mengubah causal loop ke dalam bentuk diagram alir (flow diagram). Dia-

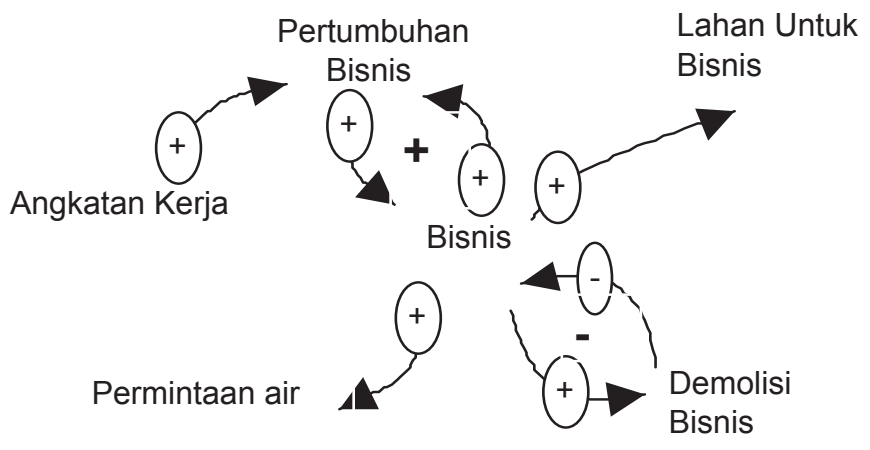

Gambar 4. Submodel Bisnis 


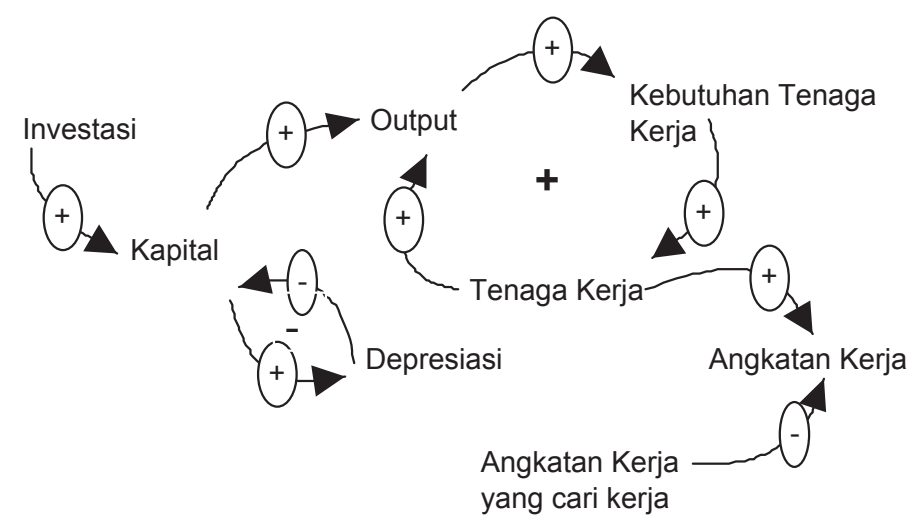

Gambar 5. Submodel PDRB dan Tenaga kerja

gram alir tersebut memperlihatkan keterkaitan antara variabel-variabel dalam model dan penyusunan persamaan matematis yang menyatakan hubungan antar variabel-variabel tersebut. Selanjutnya diagram alir yang telah dilengkapi dengan persamaan matematis tersebut diolah sehingga proses simulasi dapat dilakukan.

\section{(3) Pengujian Model dan Analisis Kebijakan}

Pada langkah ini suatu kumpulan pengujian dilakukan terhadap model untuk menegakkan keyakinan terhadap kesahihan model dan sekaligus mendapatkan pemahaman terhadap tendensi-tendensi internal sistem. Dalam penelitian ini pengujian model dilakukan dengan cara memastikan hasil simulasi model dapat mengikuti pola historis dan pola hipotesis yang diduga oleh peneliti. Setelah memastikan hal tersebut dapat dipenuhi, selanjutnya dilakukan simulasi terhadap beberapa alternatif kebijakan yang diajukan oleh peneliti. Peneliti mengajukan alternatif kebijakan baik dari sisi suplai maupun permintaan.

Alternatif pertama berupaya mengatasi kekurangan air dengan menambah volume produksi air PDAM melalui kebijakan melalui penambahan sumber air baru. Karena menambah sumur baru sulit dilakukan, maka diusulkan pula penambahan suplai air melalui kebijakan pengendalian kebocoran. Alternatif kebijakan ketiga berupaya mengatasi kekurangan air dari sisi permintaan yaitu dengan cara menekan laju pertumbuhan konsumen air melalui penggalakan kembali kegiatan Keluarga Berencana (KB) untuk menurunkan tingkat fertilitas.
HASIL DAN PEMBAHASAN

\author{
Uji Validitas Model
}


(a)

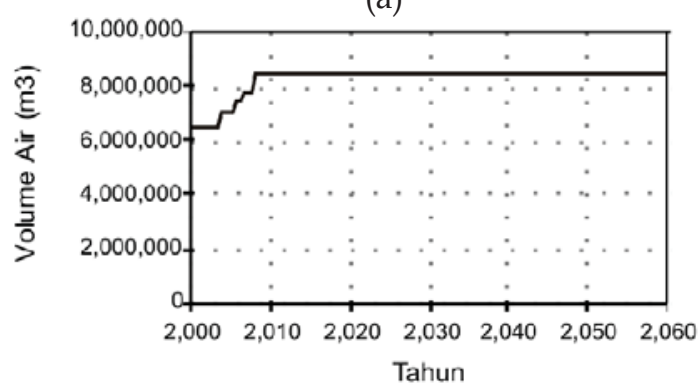

(c)

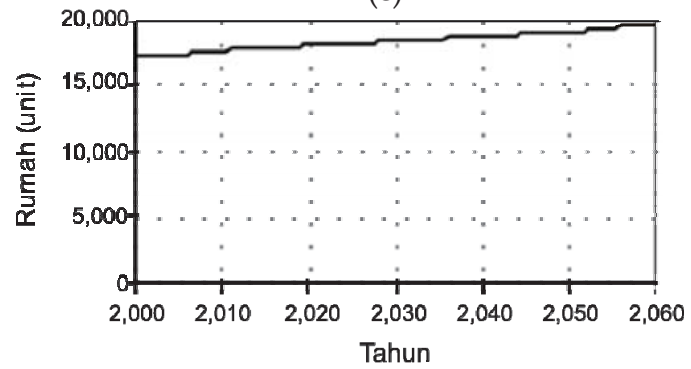

(b)

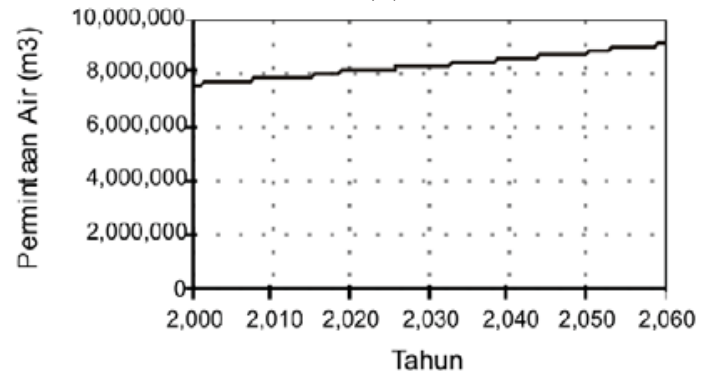

(d)

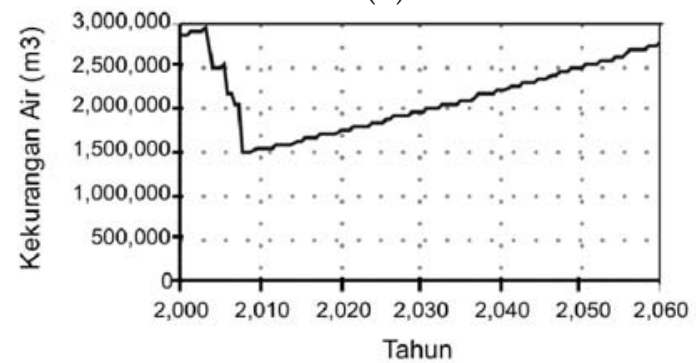

Gambar 7. Hasil Simulasi Model Dasar, Tahun 2000 - 2060

\section{Simulasi}


(a)

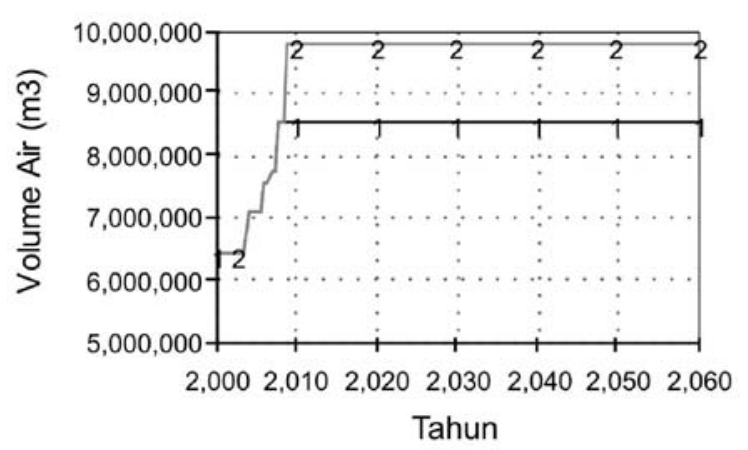

(b)

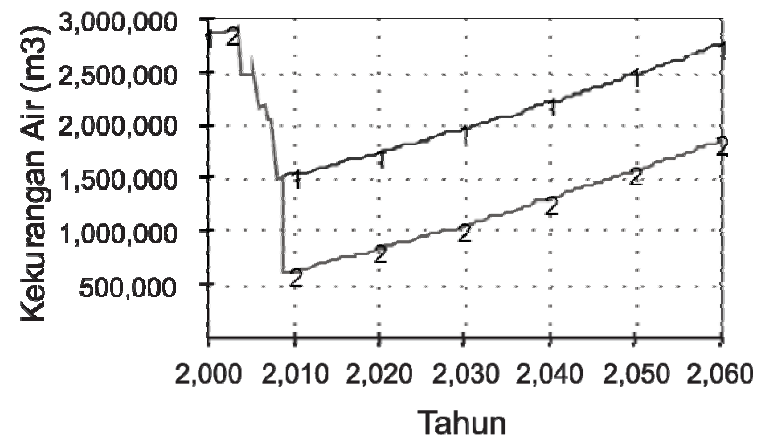

(c)

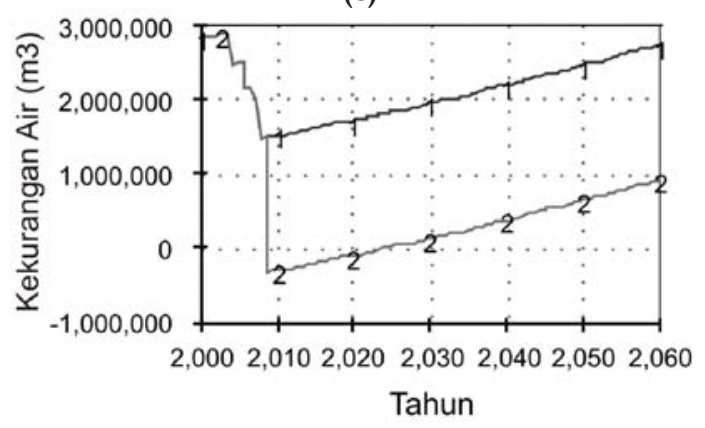

Gambar 8. Hasil Simulasi Kebijakan Penambahan Sumber Air, Tahun 2000-2060 


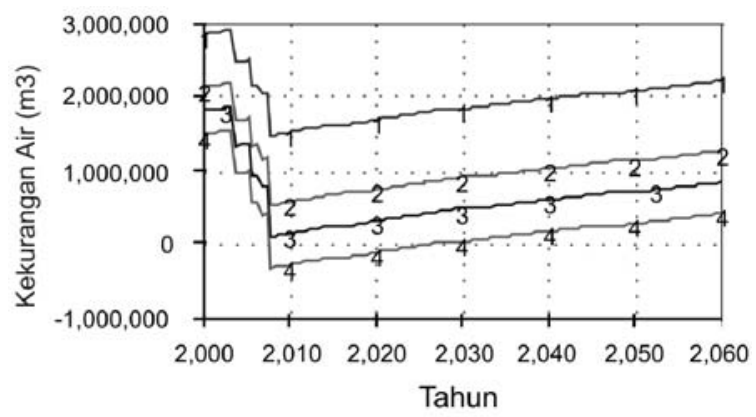

Gambar 9. Hasil Simulasi Kebijakan Pengendalian Tingkat Kebocoran, Tahun 2000-2060

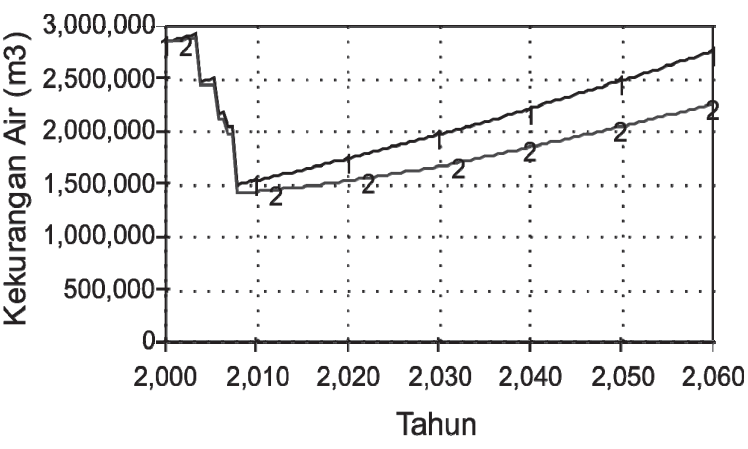

Gambar 11. Hasil Simulasi Kebijakan Pengendalian Tingkat Kelahiran, Tahun 2000-2060

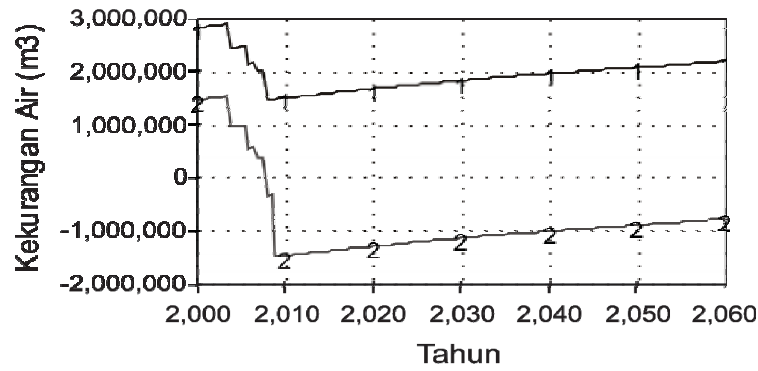

Gambar 10. Hasil Simulasi Kebijakan Penambahan Kapasitas 40 liter/detik dan Pengendalian Tingkat Kebocoran 5 persen, Tahun 2000-2060

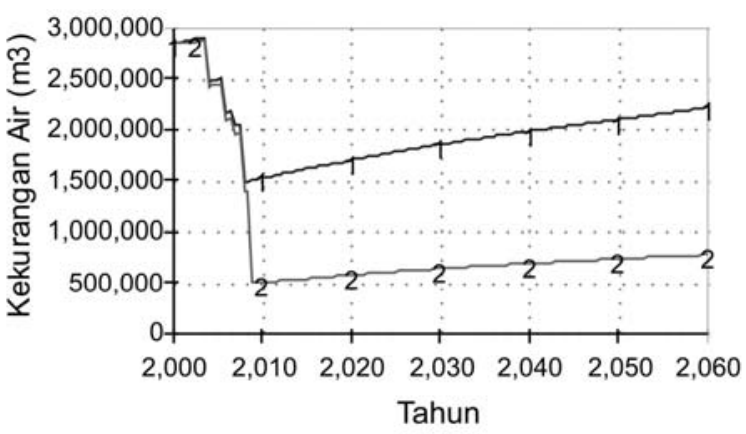

Gambar 12. Hasil Simulasi Kebijakan Penambahan Kapasitas 40 liter/detik dan Pengendalian Tingkat Kelahiran 0,1\%, Tahun $2000-2060$ 


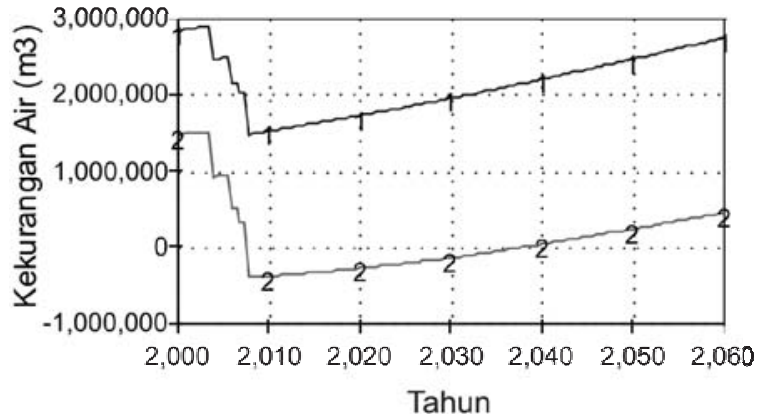

Gambar 13. Hasil Simulasi Kebijakan Pengendalian Tingkat Kebocoran 5\% dan Pengen dalian Tingkat Kelahiran 0,1\%, Tahun 2000- 2060

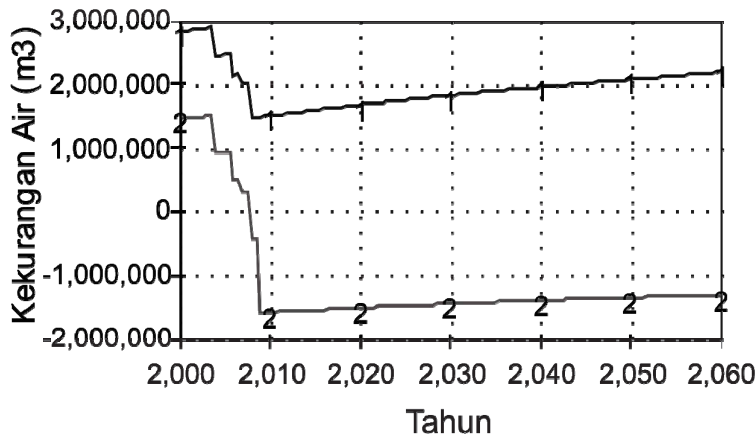

Gambar 14. Hasil Simulasi Kebijakan Penambahan Kapasitas 40 liter/detik, Pengendalian Tingkat Kebocoran 5\% dan Pengendalian Tingkat Kelahiran 0,1\%, Tahun 20002060

\section{SIMPULAN}

Berdasarkan hasil analisis dan pembahasan dapat disimpulkan:

Beberapa faktor yang mempengaruhi permintaan air PDAM di Salatiga adalah jumlah penduduk, pendapatan per kapita, aktivitas bisnis, dan tarif PDAM yang meningkat 62 persen pada tahun 2003.

Fenomena permintaan air di Salatiga dapat dinyatakan dengan model yang secara teknis disajikan dalam causal loop. Berdasarkan model tersebut dan sesuai dengan kenyataan, Salatiga mengalami kekurangan air bersih, khususnya yang disalurkan oleh PDAM. Hal tersebut terjadi karena permintaan air yang semakin meningkat sementara volume produksi air cenderung tetap. Penambahan volume produksi air baru dilakukan oleh PDAM setelah terjadi kekurangan air, yaitu pada tahun 2004, 2006, 2007 dan 2008. Penambahan volume air tersebut, berdasarkan data riil dan berdasarkan simulasi model, belum dapat mengatasi kekurangan air di Salatiga. Oleh karena itu dibutuhkan beberapa kebijakan untuk mengatasi kekurangan air tersebut.

Dengan asumsi kondisi mata air konstan dan kondisi air tanah tidak berubah, maka bisa diambil beberapa alternatif kebijakan dan hasil simulasi (Lampiran).

Berdasarkan simpulan di atas dan dengan pertimbangan PDAM sebaiknya melakukan kebijakan yang dapat dikendalikannya, maka peneliti menyarankan kepada Pemkot Salatiga khususnya PDAM Salatiga, untuk mengatasi kekurangan air dengan kebijakan pengendalian tingkat kebocoran. Hasil simulasi menunjukkan, kebijakan ini lebif efektif dari pada kebijakan penambahan kapasitas produksi dan 
pengendalian tingkat kelahiran. Apalagi untuk mengatasi kebocoran, PDAM hanya perlu melakukan perbaikan pipa-pipa transmisi maupun distribusi. Sedangkan untuk melakukan kebijakan penambahan kapasitas produksi, PDAM harus berusaha mencari sumber air baru yang tidak mudah dilakukan. Selain itu apabila PDAM mencari sumber air dengan membuat sumur dalam (sumur artesis) akan menyebabkan kerusakan lingkungan yang berakibat menipisnya cadangan air bawah tanah.

Beberapa hal yang perlu dilakukan untuk penelitian selanjutnya adalah:

Menganalisis kebijakan apa yang lebih menguntungkan untuk dilakukan oleh PDAM Salatiga. Oleh karena itu analisis yang dapat dilakukan adalah menghitung manfaat dan biaya dengan cost and benefit analysis dari kebijakan pembangunan sumber air baru, kebijakan pengendalian kebocoran dan kombinasi kebijakan pembangunan sumber baru serta pengendalian kebocoran.

Memodelkan permintaan dan penawaran air di Salatiga dengan memasukkan perubahan ketersediaan air permukaan maupun air tanah yang dipengaruhi oleh faktor cuaca, curah hujan, dan alih fungsi lahan sehingga sumber air tidak konstan.

Memodelkan permintaan air di Salatiga dengan memasukkan konflik kepentingan antar daerah atas sumber air terkait dengan adanya otonomi daerah.

\section{DAFTAR PUSTAKA}

Badan Pusat Statistik. 2006. Salatiga dalam Angka. Salatiga: BPS.

Barnett, Tim P. 2007. When Will Lake Mead Go Dry?, http://www.agu.org/journals

Dumairy. 1992. Ekonomika Sumber Daya Air: Pengantar ke Hidrodynamica. Yogyakarta: BPFE

Fauzi, Akhmad. 2006. Ekonomi Sumber Daya Alam dan Lingkungan, Jakarta: Gramedia Pustaka Utama.

Gaspersz, Vincent .2004. Sistem Manajemen Terintegrasi: Balanced Scorecard dengan Six
Sigma untuk Organisasi Bisnis dan Pemerintah. Jakarta: Gramedia.

Herinto, Deno. 2005. Analisis Faktor-Faktor yang mempengaruhi Permintaan Air Minum oleh Rumah Tangga pada PDAM Kota Magelang, Thesis S-2,UGM: Fakultas Ekonomi dan Bisnis (tidak dipublikasikan).

Hosking, SG. dan M du Preez. 2004. A Cost Benefit Analysis of the Working for Water Programme on Selected Sites in South Africa, www.wrc.org.za/archives.

Huerta, Juan M. 2004. A System Dynamics Approach to Conflict Resolution in Water Resources the Model of Lerma - Chapala Watershed, www.systemdynamics.org.

Kalangi, Bintang. 2002. Matematika Ekonomi dan Bisnis, Jakarta: Salemba Empat.

Khan, Shabaz. 2007. System Dynamics Modeling for Water Saving and Conjunctive Water Management. www.abareconomics.com

Kumar, Rakesh. 2005. Water Resources of India, www.ias.ac.in

Kusdiyanto dan Agung Riyardi. 2007. Air PDAM dan Air Sulingan dalam Konsumsi Air di Kota Surakarta. Jurnal Ekonomi Pembangunan FE UMS. Vol. 8, No. 1, Juni. Hlm. 28-35. Surakarta: BPPE: FE Universitas Muhammadiyah Surakarta.

Kusworo, Meindro B. 2005. Analisis manfaat dan Efisiensi Pembangunan Instalasi Air Bersih Bribin di Kabupaten Gunung Kidul, Skripsi S-1,UGM: Fakultas Ekonomi dan Bisnis (tidak dipublikasikan).

Parrachino, Irene. 2006. Cooperative Game Theory and Its Application to Natural, Environmental and Water Resources Issues: Application to Water Resources, www.wds. worldbank.org

Partowidagdo, Widjajono. 2004. Mengenal Pembangunan dan Analisis Kebijakan, Bandung: Program Pascasarjana Studi Pembangunan ITB.

Patton, Carl V. 1986. Basic Method of Policy Analysis and Planning, USA: Prentice Hall. 
Pekuwali, Umbu L.. 2005. Evaluasi dan Rencana Pengembangan Sistem Distribusi Air Bersih di Kecamatan Kota Waingapu Kabupaten Sumba Timur, Jurnal Purifikasi, 6(2), p.109-114.

Saysel, Ali K. 2007. System Dynamics: Systemic Feedback Modeling for Water Resources Management, www.dsi.gov.tr

Sterman, John D. 2000. Business Dynamics System Thinking and Modeling for a Complex World, Singapura: McGraw Hill.

Sukirno, Sadono. 2002. Pengantar Teori Mikroekonomi. Jakarta: Rajawali Pers.

Syarif, Fitriyeni N. 2004. Pengaruh PDRB Per Kapita terhadap Efektivitas Penerapan Tarif Air Minum dan Pendapatan PDAM di Provinsi Sumatera Barat, Thesis s-2, UGM: Fakultas Ekonomi dan Bisnis (tidak dipublikasikan).

Tangirala, Anil K. 2003. Modeling Adaptive Water Quality Management Strategies Using System Dynamics Simulation, www.iseis. org /eia/pdfstartasp.
Tasrif, Muhammad. 2006. Analisis Kebijakan Menggunakan Model System Dynamics, Bandung: Program Magister Studi Pembangunan ITB.

Tidwell, Vincent C. 2004. System Dynamics Modeling for Community-Based Water Planning: Aplication to the Middle Rio Grande, http://waterportal.sandia.gov.

Todaro, Michael P. 2006. Economic Development, USA: The Aison Wesley.

Varian, H.R. 1992. Microeconomic Analysis, 3rd edition, New York: W.W. Norton and Company.

Volpe, Joe dan Charlie Voss. 2005. Using Dynamic System Models for Water Use Accountability and Planning in Georgia, www.uga.edu/water/GWRC/Papers. 


\section{LAMPIRAN}

Tabel 1. Skenario Kebijakan dan Hasil Simulasi

\begin{tabular}{|c|c|}
\hline Skenario Kebijakan & Hasil Simulasi Kebijakan \\
\hline $\begin{array}{l}\text { - Penambahan kapasitas produksi } \\
\text { (volume air) sebesar } 40 \text { liter/detik } \\
\text { pada tahun } 2009\end{array}$ & $\begin{array}{l}\text { Kekurangan air berkurang sekitar } 1,2 \text { juta } \mathrm{m}^{3} \text {, tetapi } \\
\text { masih terjadi kekurangan air sekitar } 500000 \mathrm{~m}^{3}\end{array}$ \\
\hline $\begin{array}{l}\text { - Penambahan kapasitas produksi } \\
80 \text { liter/detik pada tahun } 2009\end{array}$ & $\begin{array}{l}\text { Kekurangan air tidak terjadi pada tahun 2009, tetapi } \\
\text { kembali terjadi pada tahun } 2022\end{array}$ \\
\hline $\begin{array}{l}\text { - Pengendalian tingkat kebocoran } \\
\text { menjadi } 5 \text { persen (dari semula } 26 \\
\text { persen) }\end{array}$ & $\begin{array}{l}\text { Kekurangan air dapat diatasi pada tahun } 2009 \text { tetapi } \\
\text { kekurangan air kembali terjadi pada tahun } 2021\end{array}$ \\
\hline $\begin{array}{l}\text { - Penambahan kapasitas produksi } \\
40 \text { liter/detik dan pengendalian } \\
\text { tingkat kebocoran } 5 \text { persen }\end{array}$ & $\begin{array}{l}\text { Kekurangan air tidak terjadi lagi pada tahun 2009, } \\
\text { bahkan sampai tahun } 2060\end{array}$ \\
\hline $\begin{array}{l}\text { - Mengurangi tingkat kelahiran dari } \\
0,56 \text { persen menjadi 0,1 persen }\end{array}$ & $\begin{array}{l}\text { Masih terjadi kekurangan air, karena dampak tingkat } \\
\text { kelahiran yang rendah tidak terlalu mempengaruhi } \\
\text { kekurangan air }\end{array}$ \\
\hline $\begin{array}{l}\text { - Penambahan kapasitas produksi } \\
40 \text { liter/detik dan pengendalian } \\
\text { tingkat kelahiran 0,1 persen }\end{array}$ & $\begin{array}{l}\text { Masih terjadi kekurangan air sekitar } 500000 \mathrm{~m}^{3} \text { pada } \\
\text { tahun } 2009 \text {, tetapi kenaikan kekurangan air pada } \\
\text { tahun berikutnya tidak terlalu tinggi }\end{array}$ \\
\hline $\begin{array}{l}\text { - Pengendalian tingkat kebocoran } 5 \\
\text { persen dan pengendalian tingkat } \\
\text { kelahiran } 0,1 \text { persen }\end{array}$ & $\begin{array}{l}\text { Kekurangan air dapat diatasi sampai tahun } 2032 \\
\text { setelah itu kekurangan air kembali terjadi }\end{array}$ \\
\hline $\begin{array}{l}\text { - Penambahan kapasitas produksi } \\
40 \text { liter/detik, pengendalian } \\
\text { tingkat kebocoran } 5 \text { persen, dan } \\
\text { pengendalian tingkat kelahiran } 0,1 \\
\text { persen }\end{array}$ & $\begin{array}{l}\text { Kekurangan air dapat diatasi sampai tahun 2060, } \\
\text { bahkan pada tahun } 2060 \text { volume air masih tersisa } \\
696.772 \mathrm{~m}^{3}\end{array}$ \\
\hline
\end{tabular}

